\title{
H3-3B Gene
}

National Cancer Institute

\section{Source}

National Cancer Institute. H3-3B Gene. NCI Thesaurus. Code C113760.

This gene plays a role in nucleosome assembly. 